\title{
Macro- and Microelement Contents of Fruiting Bodies of Wild-Edible Mushrooms Growing in the East Black Sea Region of Turkey
}

\author{
Faik A. Ayaz ${ }^{*}$, Hülya Torun ${ }^{1}$, Ahmet Colak $^{2}$, Ertuğrul Sesli $^{3}$, Mark Millson $^{4}$, Robert H. Glew ${ }^{5}$ \\ ${ }^{1}$ Department of Biology, Karadeniz Technical University, Trabzon, Turkey; ${ }^{2}$ Department of Chemistry, Karadeniz Technical University, \\ Trabzon, Turkey; ${ }^{3}$ Department of Biology Education, Karadeniz Technical University, Trabzon, Turkey; ${ }^{4}$ National Institute of \\ Occupational Health and Safety (NIOSH), Cincinnati, Ohio, U.S.A; ${ }^{5}$ Department of Biochemistry and Molecular Biology, School of \\ Medicine, University of New Mexico, Albuquerque, New Mexico, U.S.A. \\ E-mail: faa@ktu.edu.tr
}

Received November $20^{\text {th }}, 2010$; revised January $2^{\text {nd }}, 2011$; accepted January $23^{\text {rd }}, 2011$.

\begin{abstract}
Eleven different wild-edible mushroom species growing in the Black Sea region of Turkey were analysed for their element content. Specimens of mushrooms were gathered in Trabzon, Giresun and Ordu and analyzed for 31 elements by ICP-OES, four of which (Be, Sb, Te and Ti) were not detected. Whereas some minerals including Ag, As, Cd, La, Mo, $\mathrm{Pb}, \mathrm{Se}, \mathrm{Y}$ and $\mathrm{Zr}$ were detected in just a few mushroom species, another 18 minerals were found in all 11 species. All element concentrations were expressed on a dry weight basis (d.w.). With regard to nutritionally important amounts of essential and trace minerals, the element content ( $\mu \mathrm{g} / \mathrm{g} \mathrm{d.w.)} \mathrm{of} \mathrm{mushroom} \mathrm{samples} \mathrm{ranged} \mathrm{from} 21800-39800$ for $\mathrm{K}$, 2590 - 14000 for P, 268 - 1600 for Ca, 561 - 1210 for Mg, 74 - 829 for Fe, 11.2 - 321 for Cu, 36.2 - 241 for Zn, 14.1 76.5 for Mn and 0.13 - 2.85 for Co. Small amounts of toxic metals such as As, Cd and Pb were found in all 11 mushroom species. Laccaria laccata contained a large amount of As (145 $\mu \mathrm{g} / \mathrm{g} \mathrm{d.w.).} \mathrm{These} \mathrm{results} \mathrm{show} \mathrm{that} \mathrm{the}$ investigated mushrooms can be a useful component for human diets because of their high content of many essential minerals and trace elements and low content of toxic metals.
\end{abstract}

Keywords: Wild-Edible Mushrooms, Mineral Content, Toxic Metals, Trace Elements, Turkey

\section{Introduction}

Hunger has increased in the world over the past several years due to rising food prices and food scarcity caused in part by the diversion of farmland from the production of foods to the generation of ethanol for motor vehicles. These circumstances have led populations in many parts of the world to search for alternative food sources that would contribute to satisfying their nutritional needs. In this regard, many people worldwide collect wild-edible mushrooms to supplement their diets. However, since in many cases our knowledge of the mineral composition of wild-edible mushrooms is incomplete, there is a need for studies that will provide this information.

Mushrooms are an important class of organisms in nature and can be found almost everywhere on the earth. The macrofungi that includes numerous wild-edible and cultivated species do not normally constitute a large portion of the human diet; however, interest in the consump- tion of wild and cultivated mushrooms is increasing in many countries due to awareness of their high content of various essential nutrients, including trace minerals [1-10]. In this respect, the fact that wild mushrooms accumulate large amounts of both macro- and trace minerals has prompted researchers to analyze them for their metal contents, especially since many mushrooms accumulate high levels of heavy metals such as cadmium, mercury, lead, copper and arsenic $[3,11]$ that can have severe toxicological effects on humans, even at very low levels.

Several factors may affect the accumulation and content of trace elements and heavy metals in mushrooms. During the past two decades, in addition to reporting on heavy metals in mushrooms, many studies have also investigated the contents of both nutritionally significant major and trace minerals in macrofungi in the northern hemisphere [1-8,12-19]. Some of these studies were conducted in the Black Sea region of Turkey, where numer- 
ous mushroom species grow in the country that spans the continents of Europe and Asia, [5,12-15,17-19,20-23]. The region of Turkey where the mushroom species reported herein were collected has a rich macrofungal flora [13]. In eastern Turkey, the climate is mild and rainy and all four seasons are normally wet with mild temperatures. The climate throughout the year, but especially in spring and autumn, is ideal for fungal growth. People who live in this region of the country often include mushrooms in their diet. However, data related to nutrients of wild edible mushrooms of the region are scarce. In the present study, 11 mushrooms in the Black Sea region of Turkey were analysed for their content of micronutrients. To our knowledge, no previous work on the mineral content of these mushroom species has been reported either from the region or from other habitats around. The present study reports the mineral content of fruiting bodies of 11 wild-edible macrofungi samples collected from the Black Sea region of Turkey determined using an inductively coupled plasmaoptical emission spectrometer (ICP-OES).

\section{Materials and Methods}

\subsection{Collection of Mushrooms}

Fruiting bodies of 11 wild-edible mushrooms (Laccarialaccata, Leucopaxillus giganteus, Russula rosea, Cantharellus cibarus, Tricholoma saponaceum var. saponaceum, Agaricus arvensis, Boletus edulis, Clavulina rugosa, Hydnum repandum, Cantharellus tubaeformis, Lepista nuda), belonging to 8 different families were collected during field trips to the provinces of Trabzon, Giresun and Ordu between 2002 and 2005. At each collecting site the ecological and morphological properties of the specimens were recorded (Table 1). The specimens were then taken directly to the laboratory and examined microscopically using Nikon research microscopes. After spore prints were made to determine the color of the spores, the spores were then subjected to various measurements. The specimens were grouped according to taxa, lyophilized to a constant weight, and reduced to a fine powder $(20 \mathrm{mesh})$ for further chemical analysis.

Taxonomic identification was made according to criteria described elsewhere [24,25] and representative voucher specimens were deposited at a personal fungarium of Faculty of Fatih Education at the Karadeniz Technical University in Trabzon, Turkey. All extractions and determinations were performed in triplicate and the results are expressed plus or minus one standard deviation and dry weight basis (d.w.), as means.

\subsection{Mineral Analysis}

The lyophilized and milled samples were dried for seven days in a vacuum desiccator until a constant weight. Tripli- cate portions (approx. $0.2 \mathrm{~g}$ ) of each specimen were weighed into $125 \mathrm{~mL}$ Phillips beakers and digested with $20 \mathrm{~mL}$ of concentrated nitric acid and $1 \mathrm{~mL}$ of perchloric acid. The samples were covered with watch glasses and let stand for 1 hour at room temperature on a hot plate. The temperature was ramped at $50^{\circ} \mathrm{C} / 15 \mathrm{~min}$ to $150^{\circ} \mathrm{C}$ where they were left to reflux for 24 hours. The watch-glass covers were removed and the samples were taken to near dryness at the same temperature. The samples were cooled to room temperature and dissolved in $10.0 \mathrm{ml}$ of $4 \%$ nitric acid $/ 1 \%$ perchloric acid. The solutions were analyzed for their mineral and trace metal content by ICP-OES. This digestion technique does not dissolve any siliceous material present in the samples. The results are expressed as $\mu \mathrm{g} / \mathrm{g}$ dry weight (d.w.).

\subsection{Statistical Analysis}

Data are the three separate extractions and determineations of completely random experimental design. Duncan's Multiple Range Test was used to determine the statistical significance of differences among the means (SAS Institute Inc., Cary, NC, USA). Means were compared within each row of the data. For comparisons among the means analysis of variance was used.

\section{Results and Discussion}

The families of mushroom species used in this study, their habitat and geographical locations are given in Table 1 and all element concentrations are given in Table $\mathbf{2}$. Thirty one minerals were scanned; however, since detectable levels of $\mathrm{Be}, \mathrm{Sb}, \mathrm{Te}$ and $\mathrm{Tl}$ were not found in the samples, these metals were excluded from the tables.

The element concentrations varied significantly not only among the muhroom species but also wihin a particular genus (Table 2, $\mathrm{p}<0.05$ ). The limit of detection and average values for each element are also given in Table 2. Amounts of Ag, Cd, Co, Li, Mo, Se, Y and $\mathrm{Zr}$ for some mushroom species were below the limit of detection. The detection limits of the method for $\mathrm{Ag}, \mathrm{Cd}, \mathrm{Co}$, $\mathrm{Li}$, Mo, Y and $\mathrm{Zr}$ were $0.34,0.05,0.06,0.01,0.09,0.86$, 0.10 , and $0.25 \mu \mathrm{g} / \mathrm{g}$, respectively (see the end note of Table 2).

According to the results shown in Table 2, the highest $\mathrm{K}$ concentration was found in $T$. saponaceum var. saponaceum $(39800 \mu \mathrm{g} / \mathrm{g})$, whereas L. laccata and C. rugosa had average $\mathrm{K}$ contents that were slightly lower at (30200 $\mu \mathrm{g} / \mathrm{g}$ and $28900 \mu \mathrm{g} / \mathrm{g}$, respectively). The second most abundant element among 11 mushroom species was $\mathrm{P}$ and its content varied between 2590 and $14000 \mu \mathrm{g} / \mathrm{g}$, being remarkably high in $L$. giganteus and L. nuda. Comparatively high Ca concentrations $(1600 \mu \mathrm{g} / \mathrm{g})$ were found in C. tubaeformis followed by L. laccata $(10500 \mu \mathrm{g} / \mathrm{g})$. 
Table 1. Characterization of wild-edible mushrooms collected from the East Black Sea region of Turkey.

\begin{tabular}{|c|c|c|c|c|}
\hline $\begin{array}{l}\text { Sample } \\
\text { number }\end{array}$ & Herbarium number & Family & Species & Habitat, geographical location andcollection date \\
\hline 1 & SES 2192 & Hydnangiaceae & Laccaria laccata (Scop) Cooke & $\begin{array}{l}\text { In mixed wood in Giresun-Kesap-Alatas, } \\
10.08 .2003\end{array}$ \\
\hline 2 & SES 2564 & Tricholomataceae & Leucopaxillus giganteus (Sowerby) Singer & $\begin{array}{l}\text { Amongst grass in pastures, Trabzon-Macka } \\
\text { Sevinc } 10.09 .2002\end{array}$ \\
\hline 3 & SES 2257 & Russulaceae & Russula rosea Pers. & $\begin{array}{l}\text { Under Quercus, Ordu-Ulubey-Gürgentepe, } \\
\text { 10.09.2004 }\end{array}$ \\
\hline 4 & SES 2020 & Cantharellaceae & Cantharellus cibarus Fr. var. cibarus & $\begin{array}{l}\text { Under Carpinus orientalis in Rize-Kalkandere- } \\
\text { Zeyno, 30.08.2004 }\end{array}$ \\
\hline 5 & SES 2291 & Tricholomataceae & $\begin{array}{l}\text { Tricholoma saponaceum }(\mathrm{Fr} .) \mathrm{P} . \\
\text { Kumm. var. saponaceum }\end{array}$ & $\begin{array}{l}\text { In hardwood forest in Gümüshane- Yitirmez } \\
\text { 13.08.2002 }\end{array}$ \\
\hline 6 & SES 2222 & Agaricaceae & Agaricus arvensis Schaeff & $\begin{array}{l}\text { Amongst grass in pasture in Trabzon- } \\
\text { Akcaabat-Hidirnebi, } 12.10 .2002\end{array}$ \\
\hline 7 & SES 2141 & Boletaceae & Boletus edulis Bull. Fr. & $\begin{array}{l}\text { Under Picea in Trabzon-Sürmene-Perdos, } \\
03.10 .2004\end{array}$ \\
\hline 8 & SES 2107 & Clavulinaceae & Clavulina rugosa (Bull.) J. Schröt & $\begin{array}{l}\text { Under Picea orientalis in Giresun-Kesap- Dokuz- } \\
\text { tepe, } 09.08 .2003\end{array}$ \\
\hline 9 & SES 2021 & Hydnaceae & Hydnum repandum L. & $\begin{array}{l}\text { Under Picea orientalis in Ordu-Aybasti, } \\
26.10 .2005\end{array}$ \\
\hline 10 & SES 2110 & Cantharellaceae & Cantharellus tubaeformis (Bull.) Fr. & $\begin{array}{l}\text { Under Picea orientalis in Artvin-Yusufeli- } \\
\text { Hadozar, 07.09.2005 }\end{array}$ \\
\hline 11 & SES 2145 & Tricholomataceae & Lepista nuda (Bull.) Cooke & In garden in Trabzon-Of-Saracli, 08.09.2002 \\
\hline
\end{tabular}

A high and remarkably changing level was noted in $\mathrm{Mg}$. The $\mathrm{Mg}$ content (mean $870 \mu \mathrm{g} / \mathrm{g}$ ) ranged from 561 and $1210 \mu \mathrm{g} / \mathrm{g}$, and was highest in A. arvensis and L. nuda (1210 and $1200 \mu \mathrm{g} / \mathrm{g}$ ) and lowest in C. tubaeformis (561 $\mu \mathrm{g} / \mathrm{g})$. The average concentration of $\mathrm{Na}$ was $492 \mu \mathrm{g} / \mathrm{g}$ and its content was the highest in C. tubaeformis (669 $\mu \mathrm{g} / \mathrm{g})$ and lowest in C. rugosa $(336 \mu \mathrm{g} / \mathrm{g})$.

As revealed by ANOVA analysis, the majority of the mushroom species differed in significantly among these species in terms of macroelement concentrations (Table 2). In general, the range of macroelement concentrations in the mushrooms we studied concurs with the literature values $(\mu \mathrm{g} / \mathrm{g}$ d.w.) for $\mathrm{K}(2241$ - 45200), $\mathrm{P}(1200$ 10600), Ca (34 - 5300), Na (28 - 400) and Mg (58 - 1800) $[4,6,10,16]$. Recently, Ouzouni et al. [26] reported a higher content of $\mathrm{Mg}$ for $C$. cibarius $(866.3 \mu \mathrm{g} / \mathrm{g})$ and a lower content of $\mathrm{Mg}$ for $\mathrm{L}$. nuda $(949.8 \mu \mathrm{g} / \mathrm{g} \mathrm{d}$.w.) than those reported in the present study $(815$ and $1200 \mu \mathrm{g} / \mathrm{g}$, respectively).

The contents of $\mathrm{Co}, \mathrm{La}, \mathrm{Li}, \mathrm{Mo}, \mathrm{V}, \mathrm{Y}$ and $\mathrm{Zr}$ averaged between 0.2 and $0.8 \mu \mathrm{g} / \mathrm{g}$. The amounts of others (Ag, Ba, $\mathrm{Cd}, \mathrm{Cr}, \mathrm{Ni}, \mathrm{Pb}, \mathrm{Se}, \mathrm{Sr}$ and $\mathrm{Ti}$ ) ranged from 1.3 to $11 \mu \mathrm{g} / \mathrm{g}$, being the highest for Se. Among the elements, no satisfied biological roles for $\mathrm{Ag}, \mathrm{Ba}, \mathrm{Sr}, \mathrm{Ti}, \mathrm{Y}$ and $\mathrm{Zr}$ have been reported so far.

The $\mathrm{Cd}$ and $\mathrm{Pb}$ contents of the tested mushrooms were comparatively low (mean: 1.46 and $1.78 \mu \mathrm{g} / \mathrm{g}$ ). Measurable $\mathrm{Pb}$ was found only in one sample, namely $L$. laccata $(1.78 \mu \mathrm{g} / \mathrm{g})$. Lead is especially toxic to the growing brain and can affect the behavioral development of children, even at low concentrations. Organic lead compounds are fat-soluble and are more toxic than inorganic forms, and can pass through the placenta and thus affect a growing fetus $[8,20]$. The highest $\mathrm{Cd}$ concentration was $10.6 \mu \mathrm{g} / \mathrm{g}$ for $A$. arvensis and the lowest concentration was 0.14 $\mu \mathrm{g} / \mathrm{g}$ for C. tubaeformis. Cadmium is known to be toxic and inhibitory of many critical life processes [27]. It can be taken up directly from water and food and it has a tendency to accumulate in plants and animals [8]. Mushrooms may contain large amounts of $\mathrm{Cd}$ [8]. The ability to accumulate $\mathrm{Cd}$ is a characteristic of mushrooms [16] and is closely correlated with the presence of a genetically-determined binding compound $[8,27]$. The Cd values reported in the literature for a wide range of mushroom species were between 0.02 and $5 \mu \mathrm{g} / \mathrm{g} \mathrm{d}$.w.

The highest $(1320 \mu \mathrm{g} / \mathrm{g})$ and the lowest $(93.5 \mu \mathrm{g} / \mathrm{g})$ amounts of Al were found in C. rugosa and B. edulis, respectively. In the present study, As was detected in only two samples of macrofungi, namely, L. laccata and L. giganteus, 145 and $10.4 \mu \mathrm{g} / \mathrm{g}$, respectively. The highest amount of $\mathrm{Cu}(321 \mu \mathrm{g} / \mathrm{g})$ was found in C. rugosa and the lowest was found in $H$. repandum $(11.2 \mu \mathrm{g} / \mathrm{g})$. The mean $\mathrm{Cu}$ content of all mushrooms we studied was 70.4 $\mu \mathrm{g} / \mathrm{g}$ d.w. In the present study $\mathrm{Cu}$ levels for $H$. repandum were lower than those reported in the literature (24.3 and $89.5 \mu \mathrm{g} / \mathrm{g}$ ) [8,13]. In previous studies, $\mathrm{Cu}$ values reported for $H$. repandum ranged between 5.15 and $16.3 \mu \mathrm{g} / \mathrm{g}$ $[13,20]$. The published $\mathrm{Cu}$ values for mushrooms reported in the literature ranged from 3.8 to $107 \mu \mathrm{g} / \mathrm{g}$ [4-6,8,10,14,15,18,19,26]. A similar amount of $\mathrm{Cu}(75.1$ $\mu \mathrm{g} / \mathrm{g}$ ) was reported for L. nuda by Ouzouni et al. [26]. Kalac and Svoboda [3] maintains that $\mathrm{Cu}$ levels in the 
$100-300 \mathrm{mg} / \mathrm{kg}$ d.w. range should not be considered a human health risk. In the present study, the highest amounts of $\mathrm{Cu}(321 \mu \mathrm{g} / \mathrm{g})$ was found in C. rugosa. Our $\mathrm{Cu}$ values agree well with the data reported for L. nuda (75.1 $\mu \mathrm{g} / \mathrm{g})$ and C. cibarius $(32.5 \mu \mathrm{g} / \mathrm{g})$ in the literature [26]. The levels of $\mathrm{Cu}$ we measured in mushrooms are not considered a health risk. The recommended dietary allowances (RDA) for adults is $0.90 \mathrm{mg} \mathrm{Cu}$ /day [29].

The levels of Fe we measured in the 11 mushroom species ranged from 74 to $829 \mu \mathrm{g} / \mathrm{g}$, being the highest in C. rugosa and the lowest in B. edulis, and the average $\mathrm{Fe}$ content was $256 \mu \mathrm{g} / \mathrm{g}$. In the present study, iron was de- termined as the second most abundant of the trace elements after $\mathrm{Al}$, and its content was the highest in $C$. rugosa $(829 \mu \mathrm{g} / \mathrm{g})$ and lowest in B. edulis $(74 \mu \mathrm{g} / \mathrm{g})$. Iron content of mushroom samples in the literature has been reported to be in the 8 to $3904 \mu \mathrm{g} / \mathrm{g}$ range [4-6,8,10,14, $16,18,19]$. For $H$. repandum, the values reported in the literautre are $33.5,125,50$ and 250 and $317 \mu \mathrm{g} / \mathrm{g}$ [12,13, $19,20]$.

The Mn content in the present study averaged 41.2 $\mu \mathrm{g} / \mathrm{g}$. The Mn level found in previous studies of wildgrowing mushrooms varied between 1.2 - $329 \mu \mathrm{g} / \mathrm{g}$ d.w. [4-6,8,10,14-16,18,19]. The Mn contents of all 11 mush-

Table 2. Mineral contents ( $\mu \mathrm{g} / \mathrm{g}$ dry weight) of some wild-edible mushrooms from the East Black Sea region (Turkey). Values-represent the mean \pm SD of three separate extractions and determinations of completely random experimental design. Duncan's Multiple Range Test was used to determine the statistical significance of differences among the means (SAS Institute Inc., Cary, NC, USA). Means were compared within each row of the data. For comparisons among the means analysis of variance was used. Values with the same letter are not significantly different at $P<0.05^{1}$.

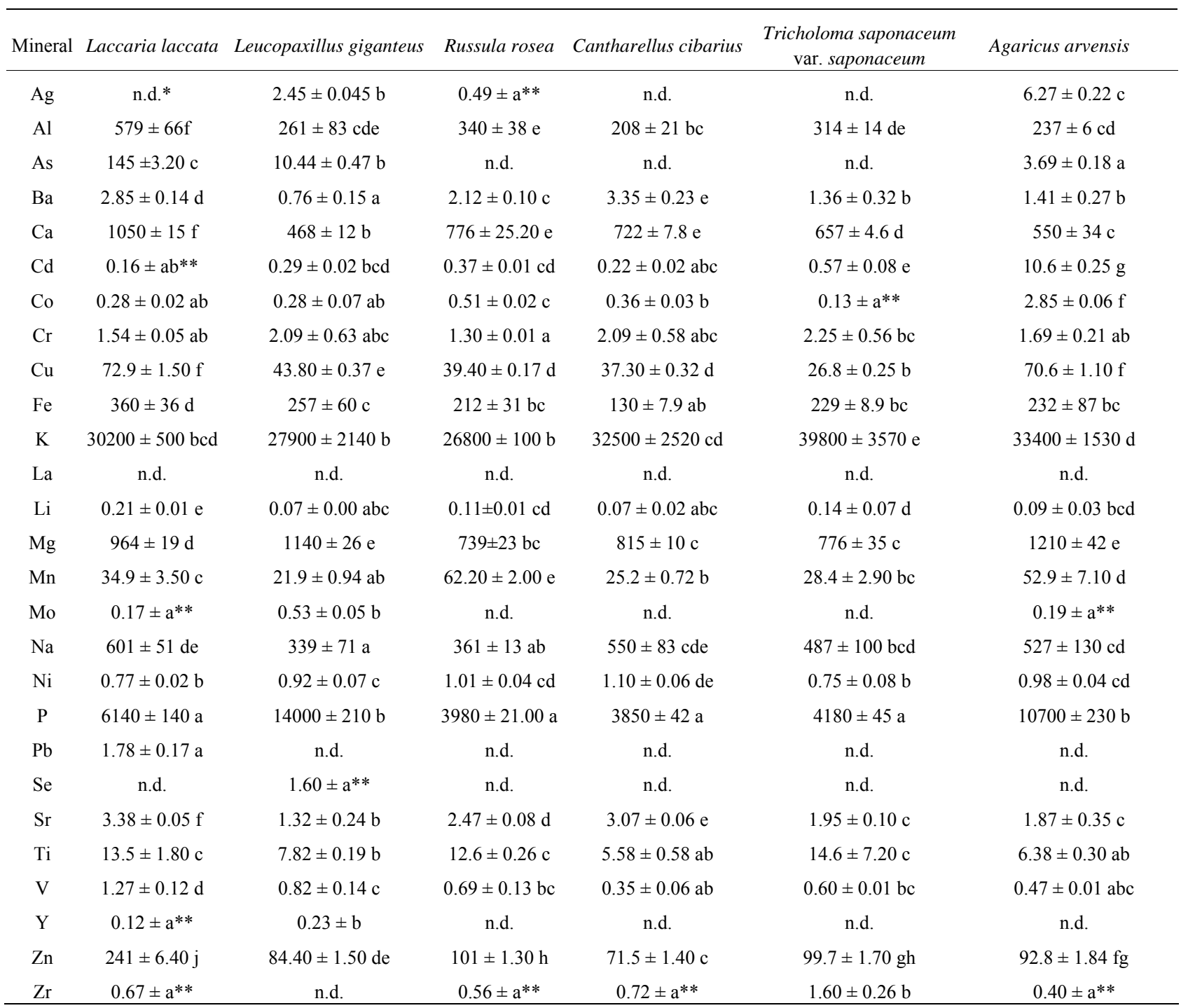



in the East Black Sea Region of Turkey

\begin{tabular}{|c|c|c|c|c|c|c|c|}
\hline Mineral & Boletus edulis & Clavulina rugosa & Hydnum repandum & Cantharellus tubaeformis & Lepista nuda & Limit values & Average values \\
\hline $\mathrm{Ag}$ & $2.50 \pm 0.15 \mathrm{~b}$ & $2.54 \pm 0.20 \mathrm{~b}$ & n.d.* & n.d. & $0.50 \pm \mathrm{a}$ & $0.40-6.27$ & 2.46 \\
\hline $\mathrm{Al}$ & $93.50 \pm 6.10 \mathrm{a}$ & $1320 \pm 140 \mathrm{~g}$ & $192 \pm 32 \mathrm{abc}$ & $192 \pm 11 \mathrm{abc}$ & $123 \pm 17 \mathrm{ab}$ & $93.5-1320$ & 351 \\
\hline As & n.d. & n.d. & n.d. & n.d. & n.d. & $3.69-145$ & 53.0 \\
\hline $\mathrm{Ba}$ & $0.53 \pm 0.02 \mathrm{a}$ & $6.22 \pm 0.47 \mathrm{f}$ & $1.24 \pm 0.09 \mathrm{~b}$ & $1.98 \pm 0.04 \mathrm{c}$ & $1.55 \pm 0.14 \mathrm{~b}$ & $0.53-6.22$ & 2.12 \\
\hline $\mathrm{Ca}$ & $268 \pm 4.7 \mathrm{a}$ & $564 \pm 25 \mathrm{c}$ & $461 \pm 43 b$ & $1600 \pm 15 \mathrm{~g}$ & $731 \pm 79 \mathrm{e}$ & $268-1600$ & 713 \\
\hline $\mathrm{Cd}$ & $1.75 \pm 0.02 \mathrm{f}$ & $0.42 \pm 0.03 \mathrm{~d}$ & n.d. & $0.14 \pm \mathrm{a}^{* *}$ & $0.17 \pm 0.01 \mathrm{ab}$ & $0.14-10.60$ & 1.46 \\
\hline $\mathrm{Co}$ & $2.07 \pm 0.09 \mathrm{e}$ & $0.64 \pm 0.22 \mathrm{~d}$ & $0.23 \pm 0.02 \mathrm{ab}$ & $0.16 \pm a^{* *}$ & $0.15 \pm \mathrm{a}$ & $0.13-2.85$ & 0.70 \\
\hline $\mathrm{Cr}$ & $1.81 \pm 0.48 \mathrm{ab}$ & $1.50 \pm 0.04 \mathrm{ab}$ & $2.74 \pm 0.68 \mathrm{c}$ & $1.57 \pm 0.44 \mathrm{ab}$ & $1.38 \pm 0.15 \mathrm{a}$ & $1.30-2.74$ & 1.82 \\
\hline $\mathrm{Cu}$ & $31.80 \pm 0.51 \mathrm{c}$ & $321 \pm 3.29 \mathrm{~g}$ & $11.2 \pm 0.16 \mathrm{a}$ & $44.6 \pm 0.95 \mathrm{e}$ & $74.9 \pm 7.70 \mathrm{f}$ & $11.2-321$ & 70.4 \\
\hline $\mathrm{Fe}$ & $74.00 \pm 12.30 \mathrm{a}$ & $829 \pm 125 \mathrm{e}$ & $199 \pm 30 \mathrm{bc}$ & $166 \pm 3.70 a b c$ & $135 \pm 47 \mathrm{ab}$ & $74.0-829$ & 257 \\
\hline K & $21800 \pm 450 \mathrm{a}$ & $28900 \pm 2160 b c$ & $38300 \pm 1700 \mathrm{e}$ & $33300 \pm 290 \mathrm{~d}$ & $27800 \pm 2670 b$ & $21800-39800$ & 31000 \\
\hline $\mathrm{La}$ & n.d. & $0.31 \pm 0.04$ & n.d. & n.d. & n.d. & 0.31 & 0.31 \\
\hline $\mathrm{Li}$ & $0.03 \pm a^{* *}$ & $0.53 \pm 0.05 \mathrm{f}$ & $0.06 \pm 0.01 \mathrm{abc}$ & $0.10 \pm 0.01 \mathrm{bcd}$ & $0.05 \pm 0.00 \mathrm{ab}$ & $0.03-0.53$ & 0.13 \\
\hline $\mathrm{Mg}$ & $680 \pm 9.2 \mathrm{~b}$ & $812 \pm 5.1 \mathrm{c}$ & $670 \pm 24 b$ & $561 \pm 8.20 \mathrm{a}$ & $1200 \pm 135 \mathrm{e}$ & $561-1210$ & 870 \\
\hline Mn & $14.10 \pm 0.58 \mathrm{a}$ & $76.5 \pm 11 \mathrm{f}$ & $20.8 \pm 2.20 \mathrm{ab}$ & $48.4 \pm 1.00 \mathrm{~d}$ & $68.3 \pm 6.80 \mathrm{e}$ & $14.1-76.5$ & 41.2 \\
\hline Mo & $0.16 \pm \mathrm{a}^{* *}$ & $0.23 \pm \mathrm{a}^{* *}$ & n.d & n.d & $1.65 \pm 0.17 \mathrm{c}$ & $0.16-1.65$ & 0.48 \\
\hline $\mathrm{Na}$ & $501 \pm 24 \mathrm{~cd}$ & $336 \pm 34 \mathrm{a}$ & $611 \pm 70 \mathrm{de}$ & $669 \pm 99 \mathrm{e}$ & $433 \pm 38 \mathrm{abc}$ & $433-669$ & 492 \\
\hline $\mathrm{Ni}$ & $1.29 \pm 0.07 \mathrm{f}$ & $5.09 \pm 0.07 \mathrm{~g}$ & $0.58 \pm 0.03 \mathrm{a}$ & $0.77 \pm 0.03 \mathrm{~b}$ & $1.15 \pm 0.15 \mathrm{e}$ & $0.58-5.09$ & 1.31 \\
\hline $\mathrm{P}$ & $6090 \pm 70 \mathrm{a}$ & $4150 \pm 5.80 \mathrm{a}$ & $5230 \pm 75 \mathrm{a}$ & $2590 \pm 56 \mathrm{a}$ & $12400 \pm 7230 b$ & $2590-14000$ & 6665 \\
\hline $\mathrm{Pb}$ & n.d. & n.d. & n.d. & n.d. & n.d. & 1.78 & 1.78 \\
\hline $\mathrm{Se}$ & $20.4 \pm 2.20 \mathrm{~b}$ & n.d. & n.d. & n.d. & n.d. & $1.60-20.4$ & 11 \\
\hline $\mathrm{Sr}$ & $0.75 \pm 0.03 \mathrm{a}$ & $2.79 \pm 0.08 \mathrm{e}$ & $1.26 \pm 0.21 \mathrm{~b}$ & $4.64 \pm 0.04 \mathrm{~g}$ & $2.40 \pm 0.25 \mathrm{~d}$ & $0.75-4.64$ & 2.35 \\
\hline $\mathrm{Ti}$ & $2.68 \pm 0.49 \mathrm{a}$ & $25.6 \pm 3.80 \mathrm{~d}$ & $6.79 \pm 0.63 \mathrm{ab}$ & $4.25 \pm 0.17 \mathrm{ab}$ & $2.18 \pm 0.34 \mathrm{a}$ & $2.18-25.6$ & 9.27 \\
\hline $\mathrm{V}$ & $0.21 \pm \mathrm{a}^{* *}$ & $2.54 \pm 0.58 \mathrm{e}$ & $0.45 \pm 0.03 \mathrm{ab}$ & $0.40 \pm 0.02 \mathrm{ab}$ & $0.56 \pm 0.04 \mathrm{abc}$ & $0.21-2.54$ & 0.76 \\
\hline $\mathrm{Y}$ & n.d. & $0.20 \pm b^{* *}$ & n.d. & n.d. & n.d. & $0.12-0.20$ & 0.16 \\
\hline $\mathrm{Zn}$ & $125 \pm 4.40 \mathrm{i}$ & $77.50 \pm 6.55 \mathrm{~cd}$ & $36.2 \pm 4.70 \mathrm{a}$ & $57.5 \pm 2.70 \mathrm{~b}$ & $86.2 \pm 8.60$ ef & $36.2-241$ & 97.5 \\
\hline $\mathrm{Zr}$ & $0.53 \pm \mathrm{a}$ & $0.56 \pm a^{* *}$ & n.d. & n.d. & n.d. & $0.40-1.60$ & 0.64 \\
\hline
\end{tabular}

*n.d.: not detected. **Values are between LOD (Limit of Detection) and LOQ (Limit of Quantitation); ${ }^{1}$ LOD, LOQ: Ag: 0.34, 1.15, Al: 0.26, 0.866, As: 1.0, 3.33, Ba: $0.012,0.0395$, Ca: 2.8, 9.19, Cd: 0.050, 0.167, Co: 0.058, 0.192, Cr: 0.087, 0.291, Cu: 0.48, 1.61, Fe; 1.0, 3.33, K: 0.44, 1.47, La: 0.24, 0.813, Li: 0.010, 0.0333, Mg: 0.46, 1.55, Mn: 0.010, 0.0333, Mo: 0.089, 0.297, Na:81, 270, Ni: 0.14, 0.470, P: 0.50, 167, Pb: 0.28, 0.946, Se:0.86, 2.85, Sr:0.010, 0.0333, Ti: 27, 0.908, V: 0.093, 0.311, Y: 0.10, 0.333, Zn: 0.86, 2.86, Zr: 0.25, 0.833 .

room species in the present work were in agreement with those reported in the studies cited above. In a recent study, in the same region but from different habitats the content of Mn was reported $23.5 \mathrm{ug} / \mathrm{g}$ d.w. for H. repandum and $28.8 \mathrm{ug} / \mathrm{g}$ d.w. for C. cibarius. However, Ouzouni et al. [26] reported a lower content of Mn (33.7 $\mu \mathrm{g} / \mathrm{g}$ d.w.) for $L$. nuda than we found in the present study (Table 2), while $C$. cibarius contained the same amount of this metal ( $22.2 \mu \mathrm{g} / \mathrm{g} \mathrm{d}$.w.).

All 11 mushroom species we tested were good sources of $\mathrm{Zn}$. The lowest $(36.2 \mu \mathrm{g} / \mathrm{g})$ and highest $(241 \mu \mathrm{g} / \mathrm{g})$ zinc contents were found in $H$. repandum and L. laccata, respectively. The range of $\mathrm{Zn}$ content reported for a number of different mushrooms in the literature was $5.5-253 \mu \mathrm{g} / \mathrm{g}$. [4-6,8,10,14-16,18,19,26]. More recently, the $\mathrm{Zn}$ content of $H$. repandum from the same region but from a different habitat in Turkey was reported to be 55.0 $\mathrm{mg} / \mathrm{kg}$ d.w. [19], which is much higher than the lower limit cited in the literature (37.8 $\mu \mathrm{g} / \mathrm{g}$ d.w.) [4], whereas the $\mathrm{Zn}$ content reported for C. cibarius ( $149 \mathrm{mg} / \mathrm{kg}$ d.w.)
[19] was lower than that of the upper limit reported by Sanmee and associates (253 $\mu \mathrm{g} / \mathrm{g}$ d.w.) [4] and Ouzouni et al. (54.3 $\mu \mathrm{g} / \mathrm{g}$ d.w.) [26]. We found a lower $\mathrm{Zn}$ content in $L$. nuda $(86.20 \mu \mathrm{g} / \mathrm{g})$ than that reported by Ouzouni et al. [26] for the same species from Greece ( 99.0 and 35.9 $\mu \mathrm{g} / \mathrm{g}$ ). The average $\mathrm{Zn}$ content was $97.5 \mu \mathrm{g} / \mathrm{g}$ for the 11 mushrooms we studied. The uptake of metal ions in mushrooms differs in many respects from that in plants $[3,10]$. Thus, the differences in the mineral contents of mushrooms reported in various studies can be attributed to the ecosystems in which they were grown and by environmental factors such as climate, growing conditions and soil content $[1,6,28]$.

From the above results, it is apparent that all of the mushrooms we collected from three sites in the East Black Sea region should be regarded as important sources of many essential elements (e.g., K, P, Ca, Mg) and trace minerals (e.g., $\mathrm{Fe}, \mathrm{Cu}, \mathrm{Zn}, \mathrm{Mn}, \mathrm{Co}$ ) C. rugosa seems to be especially efficient in concentrating certain minerals, including $\mathrm{Al}, \mathrm{Cu}, \mathrm{Fe}, \mathrm{Mn}$ and Ni. Noteworthy 
is the fact that the Ca content of all 11 mushroom species was low relative to many other foods, especially green leafy vegetables. The highest contents of $\mathrm{Al}(145 \mu \mathrm{g} / \mathrm{g}$ d.w.), $\mathrm{Cu}(321 \mu \mathrm{g} / \mathrm{g}$ d.w.) and $\mathrm{Fe}(829 \mu \mathrm{g} / \mathrm{g}$ d.w. $)$ were found in C. rugosa. The highest As content $(145 \mu \mathrm{g} / \mathrm{g}$ d.w.) was found in L. laccata. All 11 of the mushroom specimens contained significant amounts of $\mathrm{Mg}, \mathrm{Fe}, \mathrm{Mn}$ and $\mathrm{Zn}$.

\section{Conclusion}

All 11 of the mushroom species we studied appear to be good sources of many minerals and trace elements that are essential for humans. C. rugosa is an effective heavy metal accumulator for $\mathrm{Al}(1320 \mu \mathrm{g} / \mathrm{g}$ d.w.), followed by $\mathrm{Fe}$ and $\mathrm{Cu}$ (Table 2). Also, with the exception of L. laccata, the content of toxic metals such as $\mathrm{Pb}, \mathrm{Cd}$ and $\mathrm{As}$ was low. In general, these wild-edible mushroom species can be consumed unreservedly without any health risk. With the exception of $L$. laccata, the $\mathrm{Pb}$ level in the mushrooms we analyzed was below the level of detection.

\section{Acknowledgements}

The fourth author (ES) gratefully acknowledges the financial support and of the Scientific and Technical Research Council of Turkey (TUBITAK) (TBAG Project 2051 - 101TO68). Some of the chemicals, reagents and instrumentation used in the present study were purchased using a grant from TUBITAK (Project No: TBAG 2341 (103T152) which we gratefully acknowledge.

\section{REFERENCES}

[1] C. H. Gast, E. Jansen, J. Bierling and L. Haanstra, "Heavy Metals in Mushrooms and Their Relationship with Soil Characteristics," Chromosphere, Vol. 17, No. 4, 1988, pp. 789-799. doi:10.1016/0045-6535(88)90258-5

[2] P. Manzi, L. Gambelli, S. Marconi, V. Vivfanti and L. Pizzoferrato, "Nutrients in Edible Mushrooms: An Interspecies Comparative Study," Food Chemistry, Vol. 65, No. 4, 1999, pp. 477-482. doi:10.1016/S0308-8146(98)00212-X

[3] P. Kalac and L. Svoboda, "A Review of Trace Element Concentrations in Edible Mushrooms," Food Chemistry, Vol. 69, 2000, pp. 273-281. doi:10.1016/S0308-8146(99)00264-2

[4] R. Sanmee, B. Dell, P. Lumyomg, K. Izumori and S. Lumyong, "Nutritive Value of Popular Wild-Edible Mushroms from Northern Tailand," Food Chemistry, Vol. 82 , No. 4, 2003, pp. 527-532. doi:10.1016/S0308-8146(02)00595-2

[5] İ. Turkekul, M. Elmastaş and M. Tuzen, "Determination of Iron, Copper, Manganese, Zinc, Lead, and Cadmium in Mushroom Samples from Tokat, Turkey," Food Chemis- try, Vol. 84, No. 3, 2004, pp. 389-392.

doi:10.1016/S0308-8146(03)00245-0

[6] R. Moreno-Rojas, M. A. Diaz-Valverde, B. M. Arroyo, T. J. Gonzalez and C. J. B. Capote, "Mineral Content of Gurumelo (Amanita ponderosa)," Food Chemistry, Vol. 85, No. 3, 2004, pp. 325-330. doi:10.1016/S0308-8146(03)00264-4

[7] D. Agrahar-Murugkar and G. Subbulakshmi, "Nutritional Value of Wild-Edible Green Leaves Consumed by the Khasis of Meghalaya," Food Chemistry, Vol. 89, 2005, pp. 599-603. doi:10.1016/j.foodchem.2004.03.042

[8] P. K. Ouzouni, P. G. Veltsistas, E. K. Paleologos and K. A. Riganakos, "Determination of the Metal Content in Wild-Edible Mushroom Species from Regions of Greece," Journal of Food Composition and Analysis, Vol. 20, 2007, pp. 480-486. doi:10.1016/j.jfca.2007.02.008

[9] R. Pelkonen, G. Alfthan and O. Järvinen, "Element Concentrations in Wild-Edible Mushrooms in Finland," The Finnish Environment, Vol. 25, Helsinki, 2008, p. 21.

[10] P. Kalac, "Chemical Composition and Nutritional Value of European Species of Wild Growing Mushrooms: A Review," Food Chemistry, Vol. 113, No. 1, 2009, pp. 916. doi:10.1016/j.foodchem.2008.07.077

[11] J. Vetter, "Arsenic Content of Some Edible Mushrom Species" European Food Research and Technology, Vol. 219, 2004, pp. 71-74. doi:10.1007/s00217-004-0905-6

[12] M. Tuzen, M. Özdemir and A. Demirbaş, "Study of Heavy Metals in Some Cultivated and Uncultivated Mushrooms of Turkish Origin," Food Chemistry, Vol. 63, No. 2, 1998, pp. 247-251. doi:10.1016/S0308-8146(97)00225-2

[13] E. Sesli and M. Tuzen, "Levels of Trace Elements in the Fruiting Bodies of Macrofungi Growing in the East Black Sea Region of Turkey," Food Chemistry, Vol. 65, No. 4, 1999, pp. 453-460. doi:10.1016/S0308-8146(98)00194-0

[14] O. Isildak, I. Turkekul, M. Elmastaş and M., Tuzen, "Analysis of Heavy Metals in Some Wild-Grown Edible Mushrooms from the Middle Black Sea Region, Turkey," Food Chemistry, Vol. 86, 2004, pp. 547-552. doi:10.1016/j.foodchem.2003.09.007

[15] M. Soylak, S. Saracoğlu, M. Tuzen and D. Mendil, "Determination of Trace Metals in Mushroom Samples from Kayseri, Turkey," Food Chemistry, Vol. 92, No. 4, 2005, pp. 649-652. doi:10.1016/j.foodchem.2004.08.032

[16] M. Rudawska and T. Leski, "Macro- and Microelement Contents in Fruiting Bodies of Wild Mushrooms from the Notecka Forest in West-Central Poland," Food Chemistry, Vol. 92, No. 3, 2005, pp. 499-506. doi:10.1016/j.foodchem.2004.08.017

[17] M. Yamac, D. Yıldız, C. Sarıürkcü, M. Çelikkollu and M. H. Solak, "Heavy Metals in Some Edible Mushrooms form the Central Anatolia, Turkey," Food Chemistry, Vol. 103, No. 2, 2007, pp. 263-267. doi:10.1016/j.foodchem.2006.07.041

[18] A. Colak, Y. Kolcuoglu, E. Sesli and O. Dalman, "Biochemical Composition of Some Turkish fungi," Asian 
Journal of Chemistry, Vol. 19, No. 3, 2007, pp. 21932199.

[19] A. Colak, O. Faiz and E. Sesli, "Nutritional Composition of Some Wild-Edible Mushrooms," Turkish Journal of Biochemistry, Vol. 34, No. 1, 2009, pp. 25-31.

[20] A. Demirbaş, "Concentrations of 21 Metals in 18 Species of Mushrooms Growing in the East Black Sea Region," Food Chemistry, Vol. 75, No. 4, 2001, pp. 453-457. doi:10.1016/S0308-8146(01)00236-9

[21] M. Tuzen, "Determination of Heavy Metals in Soil, Mushroom and Plant Samples by Atomic Absorption Spectrometry," Microchemical Journal, Vol. 74, No. 3, 2003, pp. 289-297. doi:10.1016/S0026-265X(03)00035-3

[22] D. Mendil, Ö. D. Uluözlü, E. Hasdemir and A. Çă̆lar, "Determination of Trace Elements on Some Wild-Edible Mushroom Samples from Kastamonu, Turkey," Food Chemistry, Vol. 88, No. 2, 2004, pp. 281-285. doi:10.1016/j.foodchem.2004.01.039

[23] M. Tuzen, E. Sesli and M. Soylak, "Trace Element Levels of Mushroom Species from the East Black Sea Region of Turkey," Food Control, Vol. 18, 2007, pp. 806-810. doi:10.1016/j.foodcont.2006.04.003

[24] J. Breitenbach and F. Kränzlin, "Fungi of Switzerland," Verlag Mykologia, Vol. 1-5, Lucerne, Switzerland, 19842000.

[25] M. Moser, "Keys to Agarics and Boleti (Polyporales, Boletales, Agaricales, Russulales)," Stuttgart, Gustav Fischer Verlag, 1983.

[26] P. K. Ouzouni, D. Petridis, W. D. Koller and K. A. Riganakos, "Nutritional Value and Metal Content of WildEdible Mushrooms Collected from West Macedonia and Epirus, Greece," Food Chemistry, Vol. 115, No. 4, 2009, pp. 1575-1580. doi:10.1016/j.foodchem.2009.02.014

[27] J. Vetter, "Toxic Elements in Certain Higher Fungi," Food Chemistry, Vol. 48, No. 2, 1993, pp. 207-208. doi:10.1016/0308-8146(93)90060-S

[28] E. V. Crisan and A. Sands, "The Biology and Cultivation of Edible Mushrooms," Nutritional Value, Academic Press, New York, 1978, pp. 137-168. 